\title{
BASINAL BRINES AND MISSISSIPPI VALLEY-TYPE ORE DEPOSITS \\ by
}

Gregor M. Anderson

\begin{abstract}
Focussing on the conditions under which lead and zinc may have been transported and deposited to form the Mississippi Valley-Type deposits, Professor Anderson, Secretary of one of IUGS' Affiliated Organizations - the International Association of Geochemistry and Cosmochemistry - illustrates how geochemistry is being applied toward a better understanding of the origin of mineral deposits.
\end{abstract}

\section{Introduction}

Nississippi Valley-Type (MVT) deposits are concentrations of sphalerite and/or galena in carbonate host rocks. Fluorite and/or barite, pyrite and chalcopyrite are usually also present. Individual deposits may be of any size from sub-economic up to $10^{8}$ tons or so, but ore districts are commonly quite large. Individual deposits of a fairly distinctive type may occur over hundreds of square miles in most large sedimentary basins all over the world. They usually occur towards the edges of the basin or between basins (Figure 1), in unmetamorphosed and tectonically undisturbed rocks. MVT deposits derive their name from the fact that several of the largest and best-studied districts are located in the drainage basin of the Mississippi River (Figure 1).

A great many of these deposits show very strong geological evidence of being epigenetic (Ohle, 1967; Snyder, 1967), that is, mineralization can commonly be observed to occupy post-lithification features such as fractures and breccias. Other deposits are interpreted by some as syngenetic, and these are extemely interesting in view of our increasing knowledge of the Red Sea brine pools and metalliferous sediments. This article, however, considers only epigenetic deposits.

Two extremely important facts about these deposits have been established by the study of fluid inclusions, those microscopic droplets of fluid trapped during the growth of crystals (Roedder, 1960, 1967): that the ores were deposited by highly saline brines, up to ten times the salinity of sea water, and that the temperatures during deposition ranged from roughly $80^{\circ} \mathrm{C}$ to about $150^{\circ} \mathrm{C}$ and, in some cases, to near $200^{\circ} \mathrm{C}$. In addition, in many areas stratigraphic or geochemical evidence can be used to place an upper limit on the depth at which mineralization occurred. This turns out to be quite shallow, giving pressures of not more than a few hundred atmospheres.

\section{MAJOR WORKING HYPOTHESIS}

Space does not permit a historical summary of theories which have been advanced to explain the origin of these deposits, nor to give proper credit to the many geologists who have contributed to our present understanding of them as a product of the evolution of large sedimentary basins. When looked at in this way the analogy between MVT deposits and petroleum deposits is quite remarkable. These ideas have been synthesized effectively by Jackson and Beales (1967), Beales and Jackson (1968), Sangster (1970), Wolf (1976) and MacQueen (1976). Specifically, sediments at depth contain less water than they do near the surface. The process of sediment or basin dewatering gives rise to large volumes of fluids moving through the rocks. These fluids are believed to carry petroleum from source rocks to reservoir rocks ("primary migration") and to carry metals from their source rocks to the host carbonate rocks at the basin edges. Following are some aspects of this overall hypothesis.

\section{THE DEWATERING PROCESS}

During this complex process, the water content of sediments is reduced while becoming more saline (Burst, 1976; Collins, 1975). Controversy surrounds such topics as the reasons for increasing salinity with depth, the role of the montmorillonite-illite transition, the timing and depth of petroleum maturation and the mechanism of primary migration. These problems exist in the concept of lead-zinc movement and deposition, except that here "primary migration" refers to metals and sulfur rather than to organic material. Although organic rich shales are certainly the "source rocks" for petroleum, for metals a much wider range of possibilities exists, all of which have been advocated at one time or another.

\section{$\mathrm{Pb}$ and $\mathrm{Zn}$ Contents of Chloride-rich Brines}

Although these processes are not well understood, there is little doubt that they do take place. For example, chloriderich brines with significant metal contents have been found in several places:

1. The Salton Area, California (Helgeson, 1967). Brines at a depth of $1112 \mathrm{~m}$ at $300^{\circ} \mathrm{C}$ or so contain about $80 \mathrm{ppm}$ lead and $500 \mathrm{ppm} \mathrm{Zn}$.

2. The Red Sea brine (Degens and Ross, 1969; Ross, 1972) contains $0.63 \mathrm{ppm} \mathrm{Pb}$ and $5.4 \mathrm{ppm} \mathrm{Zn}$ at a temperature of $65^{\circ} \mathrm{C}$, although Ross $(1972)$ demonstrates that the temperature of the incoming brine was at least $104^{\circ} \mathrm{C}$. Other, more recent estimates summarized by Shanks and Bischoff (1977), indicate that the Red Sea brines may have had initial temperatures as high as $150^{\circ}$ to $250^{\circ} \mathrm{C}$. Also, the fact that the sediments beneath the brines contain sulfides (mainly pyrite, chalcopyrite and sphalerite) indicates that the metal content was probably initially higher than it is now.

3. In northern Alberta, Billings et al. (1969) showed the mean $\mathrm{Zn}$ content of 40 brine samples to be about $19 \mathrm{ppm}$, and bottom hole temperatures averaged about $75^{\circ} \mathrm{C}$.

4. Lead-rich brines have been reported by Lebedev (1973) from the Cheleken Peninsula. Samples contain up to about $77 \mathrm{ppm} \mathrm{Pb}$ and $5 \mathrm{ppm} \mathrm{Zn}$ at temperatures near $100^{\circ} \mathrm{C}$.

5. In the Gulf Coast region, Carpenter et al. (1974) reported the existence of a large area in Mississippi having brines at depths of 2400 to $4000 \mathrm{~m}$ containing up to about $100 \mathrm{ppm} \mathrm{Pb}$ and $360 \mathrm{ppm} \mathrm{Zn}$ at temperatures of $100^{\circ}$ to $150^{\circ} \mathrm{C}$.

Two other brines are listed in the tables of White, Hem, and Waring (1963) and White (1965) in which at least one brine contains $\mathrm{Pb}$ and $\mathrm{Zn}$ in excess of $1 \mathrm{ppm}$. On the other hand, Rittenhouse et al. (1969) list the minor element contents of 832 oil field waters, none of which have $\mathrm{Pb}$ or $\mathrm{Zn}$ in excess of $1 \mathrm{ppm}$. As Dunham (1970) says in his review, "It must not therefore be supposed that the investigation of formation waters in oil fields provides evidence of widespread active solutions capable of depositing non-ferrous metals in economic quantities". 


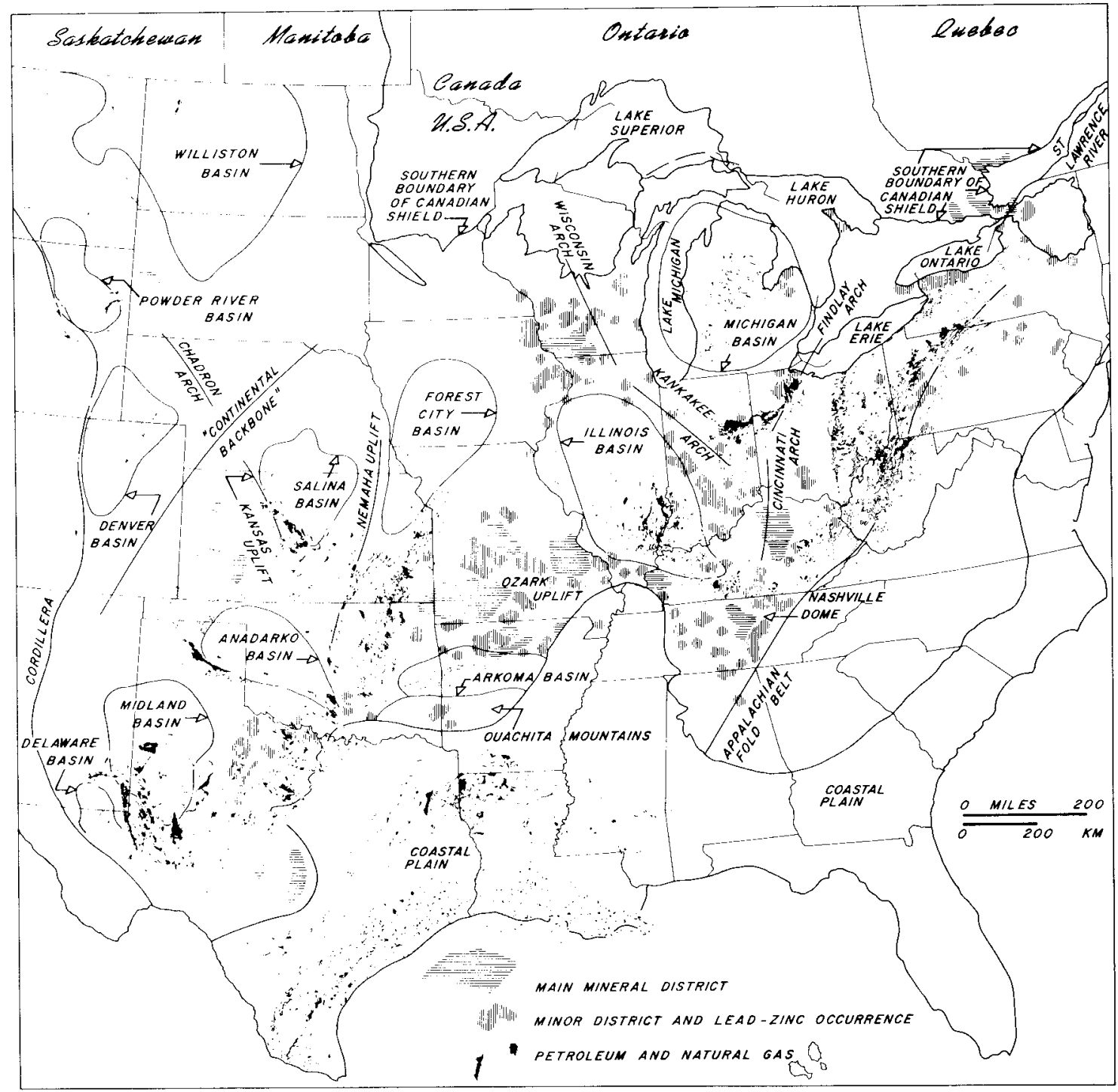

Figure 1. Map of U.S.A. showing lead-zinc districts, petroleum areas, and major basins. Note concentration of metal areas between basins, and almost complete lack of overlap between metal and petroleum areas.

In conclusion these brines may not be widespread but they do exist, and they are the most likely candidates for the ore-forming solutions in MVT ores.

\section{Concentrations in Ore-forming Fluids}

Considerations of possible rates and durations of flow of ore-forming fluids have led many people to the conclusion that metal concentrations must be greater than about one ppm, and the lack of observable sulfides in fluid inclusions led Roedder (1960) to conclude that metal concentrations were not generally more than a few hundred ppm. Thus the brines mentioned above seem to be well qualified, in this respect at lcast, to be potential ore-forming solutions.

A great deal of chemical data on these and other brines not containing as much lead and zinc has now been accumulated. Brian Hitchon (1975) reported, after comparing the compositions and other properties of these brines, that he could fine no systematic differences between them that could not be reasonably attributed to differences in temperature and host rocks. As far as we know, most subsurface brines have similar basin-evolution type origins, although some get much hotter than others due to local igneous activity (for cxample, the Salton Sea area).
Four of the five brines mentioned above lack one essential ingredient for ore-formation - reduced sulfur. In most brines the sulfur content is quite low - a few tens to a few thousands of ppm - and it is normally present as sulfate, that is, oxidized sulfur. Some brines do contain $\mathrm{H}_{2} \mathrm{~S}$ but these are invariably low in heavy metals. The Salton Sea brines are exceptional, containing 15 to $30 \mathrm{ppm} \mathrm{H}_{2} \mathrm{~S}$ as well as significant quantities of metals, but then they are at $300^{\circ} \mathrm{C}$, and cannot be directly related to MVT mineralization.

\section{Volumes of Ore-forming Fluid}

One aspect of basin dewatering which has not received enough attention is the problem of the volume of fluid required to precipitate an ore body. To precipitate 20 million tons of $5 \%$ ore from solutions carrying metals in the parts per million range requires large volumes of fluid, even given large flow rates and geologically reasonable lengths of time. These factors are summarized in Figure 2, which shows that we must think in terms of many cubic kilometres of fluid per ore deposit.

Magara (1976) has calculated the volumes of water which would be expected to pass through a given crosssectional area at various depths in a basin, based on porosity vs. depth data from the Gulf Coast Area. Using his data, it 


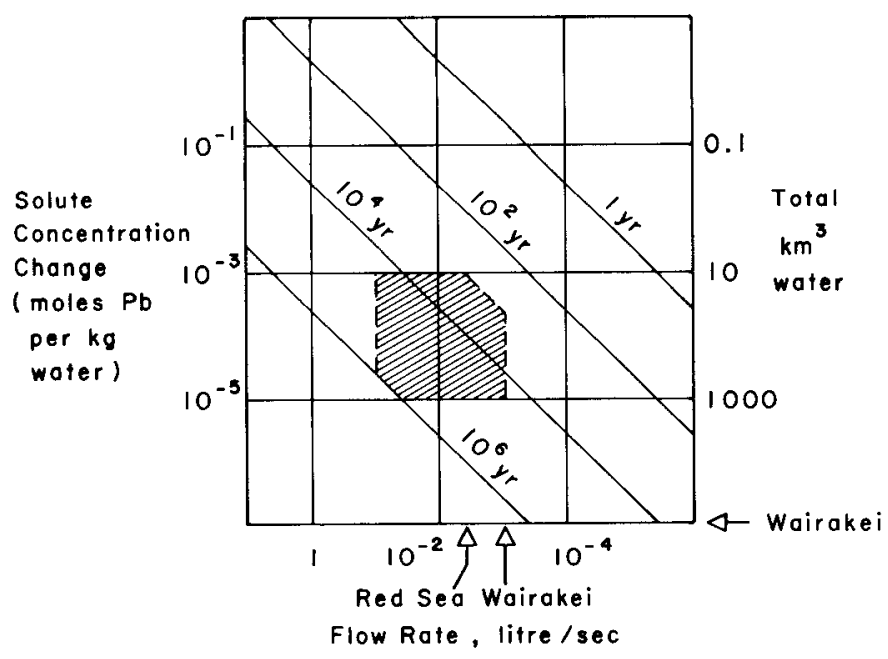

Figure 2.(Modified from Roedder, 1960). Relationship between flow rate, fluid volume, concentration change and time for deposition of 20 million tons of $5 \%$ lead ore. Geologically more reasonable conditions in shaded area. $10^{-5} \mathrm{~m} / \mathrm{kg}$ lead is approximately 2 parts per million.

can be shown that there is a real problem in deriving such large volumes of fluid from deep basinal sources (which is where the temperature and salinity have reached the required values). Other types of ore bodies (i.e. porphyry copper, volcanogenic massive sulfide) also require large fluid volumes, but they have infinitely large reservoirs (ground water, sea water) available, and cycle fluids convectively.

It is very difficult to see how this could operate in the MVT situation. As far as fluids are concerned, MVT deposits appear to be a "one-pass" situation, and the movement of sufficient volumes of very high salinity, high temperature fluids, even though they are known to exist, constitutes another problem.
METAL TRANSPORT AND DEPOSITION

The transport of metals in brines depends in part on the reduced sulfur content of the brines. In those having no reduced sulfur (all sulfur occurs as sulfate ions and various sulfate complexes), transport is readily accomplished. The metals occur dominantly as chloride complexes, and concentrations up to thousands of parts per million are possible. While the occurrence of sulfur as sulfate poses no problem as far as transport is concerned, it does create difficulties when we consider deposition, because the ores do not consist of metal sulfates but of metal sulfides. In other words, a source of reduced sulfur must be found to promote deposition if none is brought with the metals.

An alternative possibility is that the ore solutions carry both metals and reduced sulfur. In this case, we have a transport problem because metal solubilities in solutions containing appreciable reduced sulfur are very low. In fact, solubility data available at present (Anderson, 1973, 1975) indicate that it is not possible for a salt solution at $100^{\circ} \mathrm{C}$ to $150^{\circ} \mathrm{C}$ to carry both sufficient metal and sufficient reduced sulfur to form an ore deposit. Solutions may carry one or the other but not both.

This conclusion, illustrated in Figure 3, must remain tentative until more experimentation is done, because it is based on very simple solutions while the natural ones are complex, and there may be metal-complexing reactions about which we have much to learn. At the moment, the possibility of metal-organic complexing in natural solutions looks as though it may be significant. Reactions such as this would allow more metal to be carried by the solution in the presence of reduced sulfur and thus the above conclusion may need modifying. Experiments on these reactions are in progress.

\section{Different Deposition Conditions}

The reason for dwelling on this seemingly minor point about the brine chemistry is that completely different deposition conditions are called for, depending on whether reduced sulfur is carried with the metals or not, and a

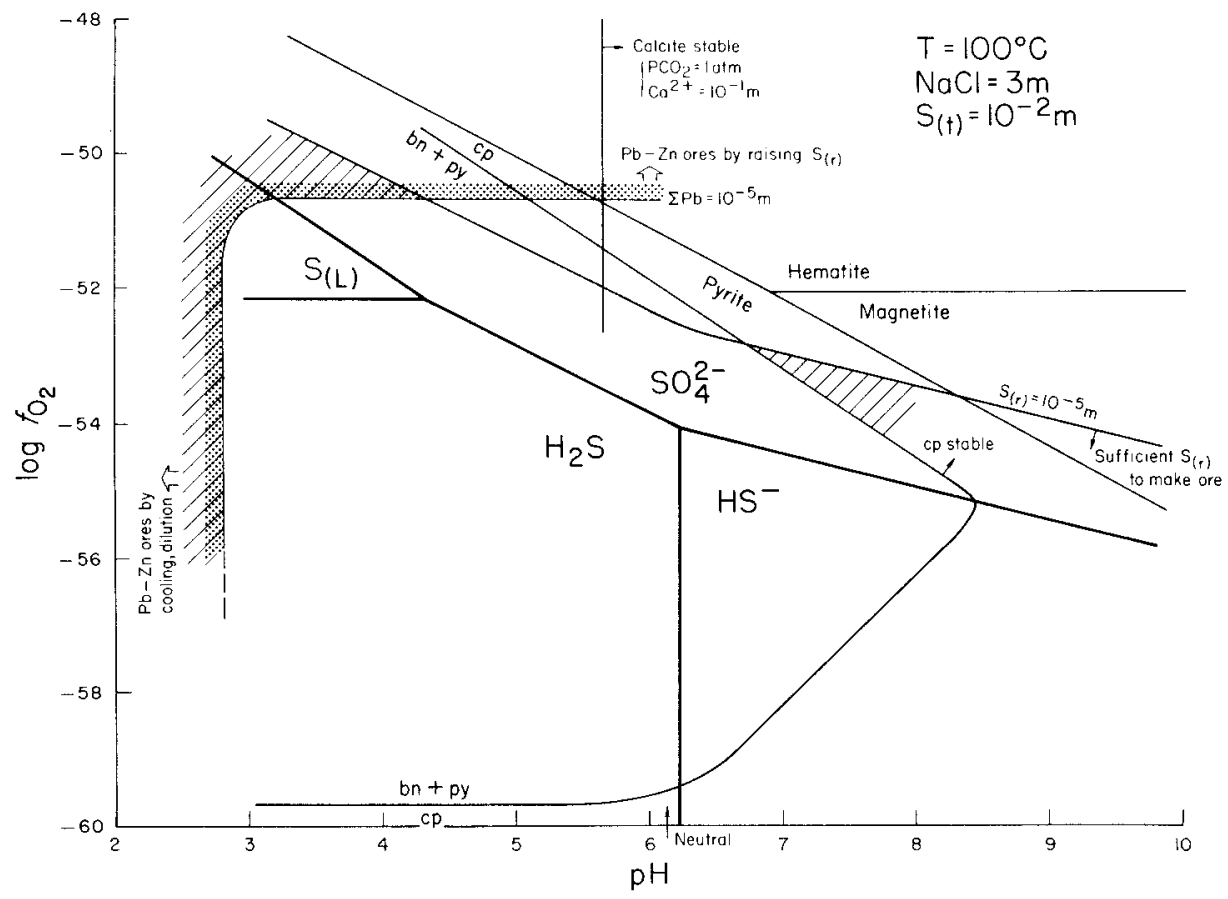

Figure 3. Galena solubility and mineral stability fields as a function of oxidation state $\left(\log \mathrm{fO}_{2}\right)$ and acidity $(\mathrm{pH})$. The diagram is overly complex for the non-specialist, but serves to indicate how solubility data can be related to mineral stability fields in attempts to understand conditions of transport and deposition. $S(r), S(t), S(L)$ : reduced, total and liquid sulfur. From Anderson (1975). 
knowledge of deposition conditions has prospecting implications. The possible reasons for deposition of sulfides from the brines are outlined in Table 1 .

Table 1

\section{REASONS FOR DEPOSITION}

1. $\mathrm{pH}$ change

2. Cooling

3. Dilution

Increase in reduced sulfur

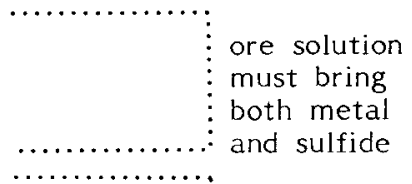

A. by reducing $\mathrm{SO}_{4}^{2-}$ already in the brine

a) internally (e.g. dissolved $\left.\mathrm{CH}_{4}\right)$

b) externally (e.g. petroleum encountered)

B. by adding $\mathrm{H}_{2} \mathrm{~S}$ to brine

a) bacterial sulfate reduction

b) thermal degradation of petroleum

c) non-bacterial sulfate reduction by organic material

d) from pre-existing sulfide minerals

Clearly, if the metal-bearing brine does not contain enough reduced sulfur to precipitate ore, then it must be supplied at the site of deposition, and this invariably involves some sort of sulfate-reduction. The only common reducing agent in the basinal environment is organic matter or petroleum, hence again, a possible link between oil and ore.

It is interesting to note that bitumen is quite common in these deposits, as are droplets of oil in fluid inclusions in the ore minerals. On the other hand, there is no occurrence of a producing lead-zinc deposit in close proximity to a petroleum deposit. In fact, as shown in Figure 1, there is a distinct antipathetic spatial relationship between petroleum and leadzinc deposits (see also Dozy, 1970). There are a variety of possible explanations for this, such as the possibility that metal-bearing brine movement occurs at a later, hotter and deeper stage in basin evolution.

Geological evidence as to the mechanism of sulfide deposition is equivocal. Opinion is divided, for example, on whether carbonates are stable during sulfide deposition (Beales, 1975), which is important in setting limits on the acidity of the solutions. Some deposits, notably Pine Point, NWT (Canada), show evidence of relatively rapid deposition and crystal growth (e.g. dendritic and hopper galenas), which would be consistent with addition of $\mathrm{H}_{2} \mathrm{~S}$ to the brines. Other deposits show evidence of very slow, near equilibrium deposition conditions over wide areas, which is difficult to reconcile with $\mathrm{H}_{2} \mathrm{~S}$ addition. Sulfur isotope data also provide ambiguous evidence.

\section{CONCLUSIONS}

Within the class of hydrothermal ore deposits (that is, those deposited from hot aqueous fluids), MVT deposits are paradoxical in that they are at the same time the simplest and the most complex. They are simple in their mineralogy, lack of metamorphism and lack of tectonic deformation, and they have lower temperatures and pressures during formation than other types of hydrothermal deposits.

However, while other types of deposits represent relatively localized phenomena (e.g. water convecting near a volcanic hot spot), MVT deposits depend on processes linked with the evolution of sedimentary basins, covering truly vast areas, considerable depths, and great lengths of time. And so, while we know a great deal about them, we sometimes feel as far as ever from a complete understanding.

This summary does not do justice to the many problems involved. For example, even more fundamental than the sulfur problem, is the timing problem. It is a discouraging fact that for most areas we have almost no idea as to the age of the mineralization event, whether it took place immediately after-lithification or millions of years later. The development of the cryogenic magnetometer and the ability to obtain paleo-poles on limestones and sulfide ores has opened up a possible solution to this problem (Beales et al., 1974).

Although there is a striking analogy between the origins of petroleum and lead-zinc deposits this has not yet led to a major breakthrough in our understanding of the origins of either. Until we can explain not only why the ores are at certain places and not at others which seem equally favorable (e.g. the Gulf Coast, West Texas), we cannot have complete confidence in the working hypothesis, or elevate it to the status of theory.

The following list of facts and ideas, based on the working hypothesis, contains implications for exploration strategy (not in any particular order):

1. Large, deep basins: the sorts of processes discussed can only take place in rather large sedimentary basins, and MVT deposits generally occur towards the edges of these (Figure 1).

2. Carbonates: within the basins, it is a fact that carbonates usually form the host rocks for MVT deposits.

3. Evaporites: the known presence of evaporite beds somewhere in the basin must be regarded as a favourable sign, in view of their role in producing brines and, by their solution, collapse breccias.

4. Cavities: not enough stress has been laid on the importance of the existence of cavities prior to ore deposition. In many districts it can be shown that the cavities existed before the ore came in. There are also theoretical reasons for believing that the ore-depositing solutions did not create the cavities. It is important to be aware of the many ways that cavities may be formed in carbonate rocks; (Callahan, 1967, lists several).

5. Unconformities: the importance of unconformities warrants special mention. In carbonate units, unconformities create the possibility for Karst structures, solution breccias and so on, which are ways of creating openings and cavities. Irregular unconformities create possibilities for pinch-outs, draped sediments, talus slopes and other sorts of traps which may sometimes be mineralized.

6. Dolomitization: this is so often associated with MVT ore that it must be regarded as a promising if not a very diagnostic sign. Although dolomitization may produce enhancement or enlargement of cavities, this process is probably more likely a result of cavities being present.

Silicification, on the other hand, although perhaps useful locally, is not a good guide to mineralization. Its presence probably depends entirely on a local source of silica such as a chert horizon.

7. Organic Material: the presence of organic material is also a promising indicator, although, as discussed above, the exact relationship between it and the ore is not yet understood.

8. Carbonate Fronts: the control of ore by carbonate fronts (the locus of shale-carbonate facies changes) has been suggested (Taylor, et al., 1975) for deposition of metals. It is envisaged that when brines are moved out of shale units into carbonates, they commonly do not need to go very far before finding open spaces and $\mathrm{H}_{2} \mathrm{~S}$ to promote precipitation. 


\section{REFERENCES}

Anderson, G.M., 1973, The hydrothermal transport and deposition of galena and sphalerite near $100^{\circ} \mathrm{C}$ : Econ. Geol., v. 68, p. 480-492.

, 1975, Precipitation of Mississippi Valleytype ores: Econ. Geol., v. 70, p. 937-942.

Beales, F.W., 1975, Precipitation mechanism for Mississippi Valley-type ore deposits: Econ. Geol., v. 70, p. 943-948.

Beales, F.W., and Jackson, S.W., 1968, Pine Point - a stratigraphical approach: Can. Mining Metallurgy Bull., v. 61, p. 867-878.

Beales, F.W., Carracedo, J.C., and Strangway, D.W., 1974, Paleomagnetism and the origin of Mississippi Valley-type Ore Deposits: Can. Jour. Earth Sci., v. 11, p. 211-223.

Billings, G.K., Kesler, S.E., and Jackson, S.A., 1969, Relation of zinc-rich formation waters, northern Alberta, to the Pine Point ore deposit: Econ. Geol., v. 64, p. 385-391.

Burst, J.F., 1976, Argillaceous sediment dewatering: Ann. Rev. Earth and Plan. Sciences, v. 4, p. 293-318.

Callahan, W.H., 1967, Some spatial and temporal aspects of the localization of Mississippi Valley-Appalachian type ore deposits: Econ. Geol. Mon. 3, p. 14-19.

Carpenter, A.B., Trout, M.L., and Pickett, E.E., 1974 , Preliminary report on the origin and chemical evolution of lead- and zinc-rich oil field brines in central Mississippi: Econ. Geol., v. 69, p. 1191-1206.

Collins, A.G., 1975, Geochemistry of Oilfield Waters: Elsevier Scientific Publishing Co., 496 pp.

Degens, E.T., and Ross, D.A., eds., 1969, Hot brines and recent heavy metal deposits in the Red Sea: New York, Springer-Verlag, $600 \mathrm{p}$.

Dozy, J.J., 1970, A geological model for the genesis of the lead-zinc ores of the Mississippi Valley, U.S.A.: Trans. Inst. Mining Metall., Sec. B, p. 163-170.

Dunham, K.C., 1970, Mineralization by deep formation waters: a review: Trans. Inst. Mining Metall., Sec. B, p. $127-136$.

Helgeson, H.C., 1967, Silicate metamorphism in sediments and the genesis of hydrothermal ore solutions, in Brown, J.S., ed., Genesis of stratiform lead-zinc-baritefluorite deposits: Econ. Geol. Mon. 3, p. 333-342.

Hitchon, B., 1975, Geochemical links between oil fields and ore deposits in sedimentary rocks. Proceedings of the Forum on Oil and Ore in Sediments: Dept. of Geology, Imperial College, London, p. 1-34.

Jackson, S.A., and Beales, F.W., 1967, An aspect of sedimentary basin evolution: The concentration of Mississippi Valley-type ores during late stages of diagenesis: Bull. Canadian Petroleum Geology, v. 15, p. 383-433.

Lebedev, L.M., 1973, Minerals of contemporary hydrotherms of Cheleken: Geochemistry Internat., v. 9, p. 485-504.

Macqueen, R.W., 1976, Sediments, zinc and lead, Rocky Mountain Belt, Canadian cordillera: Geoscience Canada, v. 3, p. 71-81.

Magara, K., 1976, Water expulsion from clastic sediments during compaction - directions and volumes: Bull. Am. Assoc. Petrol. Geol., v. 60, p. 543-553.

Ohle, E.L., 1967, The origin of ore deposits of the Mississippi Valley-type, in Symposium on the genesis of stratiform lead-zinc-barite-fluorite deposits: Econ. Geol. Mon. 3, p. 33-39.

Rittenhouse, G., et al., 1969, Minor elements in oil-field waters: Chem. Geol., v. 4, p. 181-209.
Roedder, E., 1960, Fluid inclusions as samples of the oreforming fluids: Internat. Geol. Cong., 21st, Copenhagen, part XVI, p. 218-229.

, 1967, Environment of deposition of stratiform (Mississippi Valley-type) ore deposits, from studies of fluid inclusions, in Symposium on the genesis of stratiform lead-zinc-borite-fluorite deposits: Econ. Geol.Mon. 3, p. 326-332.

, 1972, Composition of fluid inclusions: Data of Geochemistry: U.S.G.S. Prof. Paper 440-JJ.

Ross, D.A., 1972, Red Sea hot brine area: Revisited: Science, v. 175 , p. $1455-1456$.

Sangster, D.F., 1970, Metallogenesis of some Canadian leadzinc deposits in carbonate rocks: Proc. Geol. Assoc. Can., v. 22, p. 27-36.

Shanks, W.C., and Bischoff, J.L., 1977, Ore transport and deposition in the Red Sea geothermal system: a geochemical model: Geochim. et Cosmochim. Acta, v. 41, p. 1507-1519.

Snyder, F.G., 1967, Criteria for origin of stratiform ore bodies with application to southeast Missouri, in Symposium on the genesis of stratiform lead-zinc-baritefluorite deposits: Econ. Geol. Mon. 3, p. 1-13.

Spooner, E.T.C., Beckinsale, R.D., England, P.C., and Senior, A., 1977, Hydration, 180 enrichment and oxidation during ocean floor hydrothermal metamorphism of ophiolitic meta basic rocks from E. Liguria, Italy: Geochim. et Cosmochim. Acta, v. 41, p. 857-872.

Taylor, G.C., Macqueen, R.W., and Thompson, R.I., 1975, Facies changes, breccias and mineralization in Devonian rocks of Rocky mountains, Northeastern B.C.: G.S.C. paper 75-1, part A, p. 577-585.

White, D.E., Hem, J.D., and Waring, G.A., 1963, Data of Geochemistry, 6th ed., Chap. F: Chemical composition of subsurface waters: U.S.G.S. Prof. Paper 440-F, 67 pp.

White, D.E., 1965, Saline waters of sedimentary rocks, in Fluids in Subsurface Environments, Young, A. and Galley, J.E., eds.: Am. Assoc. Petrol. Geol. Memoir 4, p. 343-366.

Wolf, K.H., 1976, Ore genesis influenced by compation, Chap. 5 in Compaction of Coarse-Grained Sediments, II, G.V. Chilingarian and K.H. Wolf, eds.: Elsevier Pub. Co., p. 475-675.

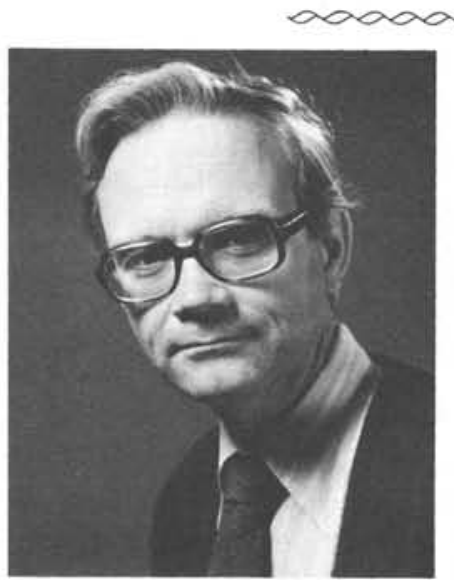

Professor G.M. Anderson

ABOUT THE AUTHOR: Professor of Geology at the University of Toronto in Canada, Greg Anderson is Associate Editor of Canadian Mineralogist and on the editorial board of Economic Geology. Appointed Secretary of the IAG $\bar{C}$ in 1977, he is this year also serving as Visiting Lecturer of the Canadian Institute of Mining and Metallurgy. 